\title{
Use of Grasses and Mixtures of Grasses for Energy Purposes
}

\author{
David Andert ${ }^{1}$, Jan Frydrych ${ }^{2}$, Ilona Gerndtová ${ }^{1}$ \\ ${ }^{1}$ Research Institute of Agricultural Engineering, p.r.i, Drnovská 50\%, 16101 Prague 6, Czech Republic \\ ${ }^{2}$ OSEVA PRO, Zubří, Hamerská Zubří
}

Correspondence to: andert@vuzt.cz

\begin{abstract}
As levels of agricultural productivity increase, there is also an increase in land area not utilized for food production. This area can be used for growing energy crops, including grasses. When land is set aside for grassing, or when the potential of perennial grasses is not utilized due to reductions in cattle herds, there is also an increased amount of grass that can be utilized for energy purposes. Experiments were carried out on the principle of single-stage anaerobic digestion within the mezophyle range. During the experiments, we measured the cumulative production of biogas and its composition. The processed grass was disintegrated by pressing and cutting. This adaptation of the material resulted in increased biogas production. The optimum proportion of grass dry matter is from 35 to $50 \%$ in the total d.m. The results of the experiments proved the suitability of grass phytomass as a material for biogas production.
\end{abstract}

Keywords: biomass production, anaerobic digestion, biogas.

\section{Introduction}

The search for new energy resources has become a worldwide phenomenon. Due to increasing levels of agricultural productivity, there has also been an increase in land set aside without food production. Grassland is of exceptional significance not only for forage production but also for non-production functions [1]. Its important functions include: water management - rainfall retention; anti erosion — i.e. protection against water and wind erosion; protection in relation to the hydrosphere - root systems reduce underground water pollution; esthetic - grassland maintains the appearance of the landscape; economic and social functions — generating jobs for people living in marginal areas. When arable land is put into the set-aside regime, the lands needs to be cultivated by cutting. Increased economic pressure for profitable agriculture is another reason why the cultivated area has been reduced, particularly in marginal regions. It may be assumed that the trend in Germany and Austria will be followed in the Czech Republic, and there will be increased social pressure on landowners, especially in tourist regions, to ensure that all grasslands are regularly maintained [1].

\section{Material and methodology}

In our experiment, we used Agrostis gigantea (Rožnovský), fescue Kora, reed canary grass Palaton, reed canary grass Lera, reed canary grass Chrifton, grassland mixture for wet conditions, grassland mixture for dry conditions, brome-grass Tacit and Ar- rhenatherum elatius Rožnovský. The experiments were performed with variants without $\mathrm{N}$ fertilization and with an $\mathrm{N}$ dose of $50 \mathrm{~kg} / \mathrm{ha} / \mathrm{a}$. The experimental crop was harvested six times in the course of a year. The biomass yield in the green and dry material was found, and also the dry matter content.

A laboratory workplace was built for producing biogas grown from a special substratum. A set of fermenters was placed in a heated water bath. Each fermenter had its own gas container to enable the biogas production quantity to be read. These small devices determine biogas production and specify other properties of the phytomass mixture of energy plants, slurry, fugate and neutralization agents. The aim of our experiment was to reduce the acidity of an organic substratum mixture processed under anaerobic conditions. An AIR LF analyzer was used to analyze the biogas that was generated. This device was further used for measuring the $\mathrm{CO}_{2}, \mathrm{CH}_{4}$ and $\mathrm{S}_{2}$ contents. A pair of larger reactors with comparative methanogenesis measurements was also available. The mixtures tested with good results in small fermenters were then verified in larger laboratory fermenters.

\section{Results and discussion}

\subsection{Yield characteristics of the investigated grass species}

On $8^{\text {th }}$ July 2010, the first harvest of energy grasses and grassland mixtures for biomass and seed production was gathered: fescue Kora, reed canary grass 
(Palaton, Lera and Chrifton), Arrhenatherum elatuis Rožnovský and brome-grass Tacit. On August 9, energy grasses and grassland mixture for biomass production and Agrostis gigantea Řožnovský for seed production were harvested. On September 8, all grassland mixtures and grass species for biomass production were harvested. On October 18, energy grass species and grassland mixtures were harvested. The dry matter yield in the same species was up to 10 tons per 1 hectare. The grassland mixture produced the highest yield of green material (48.36 t/ha) and dry matter $(9.77 \mathrm{t} / \mathrm{ha})$ for wetter conditions, in the fertilized variant. For the grass species, the highest yield was for fecsue Kora in green material (31.29 t/ha) and in dry matter $(9.36 \mathrm{t} / \mathrm{ha})$, in the fertilized variant.

The second harvest of grass species and grassland mixtures was performed on July 4. The dry matter content in the green material of the investigated grasses and mixtures increased to $29.89 \%-40.86 \%$ according to species. The grassland mixture produced the highest yield of green material for wetter conditions $(35.38 \mathrm{t} / \mathrm{ha})$, in the fertilized variant. The highest dry matter yield was for brome-grass Tacit $(12.27 \mathrm{t} / \mathrm{ha})$, in the fertilized variant.

On July 8, a harvest of grasses and grassland mixtures for biomass production was performed, and some grasses for seed production were also harvested.

The dry matter yield in the green material was from $30.59 \%$ to $42.64 \%$, according to the verified components. The grassland mixture produced the highest yield of green material for wetter conditions $(35.52 \mathrm{t} / \mathrm{ha})$, in the fertilized variant. The highest dry matter yield was for brome-grass Tacit $(12.48 \mathrm{t} / \mathrm{ha})$, in the fertilized variant. The highest seed yield was recorded for brome-grass (2.812 t/ha), in the fertilized variant. Other grass species produced a seed yield from 0.117 to $0.824 \mathrm{t} / \mathrm{ha}$. The seed yields were almost identical for the fertilized variant and for the non-fertilized variant.

On August 9, grasses and grassland mixtures for biomass production were harvested. The seed harvest for Agrostis gigantea was performed. The dry matter content in the green material ranged from $36.35 \%$ to $50.83 \%$ of the investigated components. The highest yield of green material was reported for fescue $(30.24 \mathrm{t} / \mathrm{ha})$, in the fertilized variant. The highest dry matter yield was for fescue (13.68 t/ha), in the fertilized variant. On August 9, 2005 the seed harvest of Agrostis gigantea was performed, with the yield in the non-fertilized variant amounting to $0.425 \mathrm{t} / \mathrm{ha}$, and in the fertilized variant amounting to $0.495 \mathrm{t} / \mathrm{ha}$.

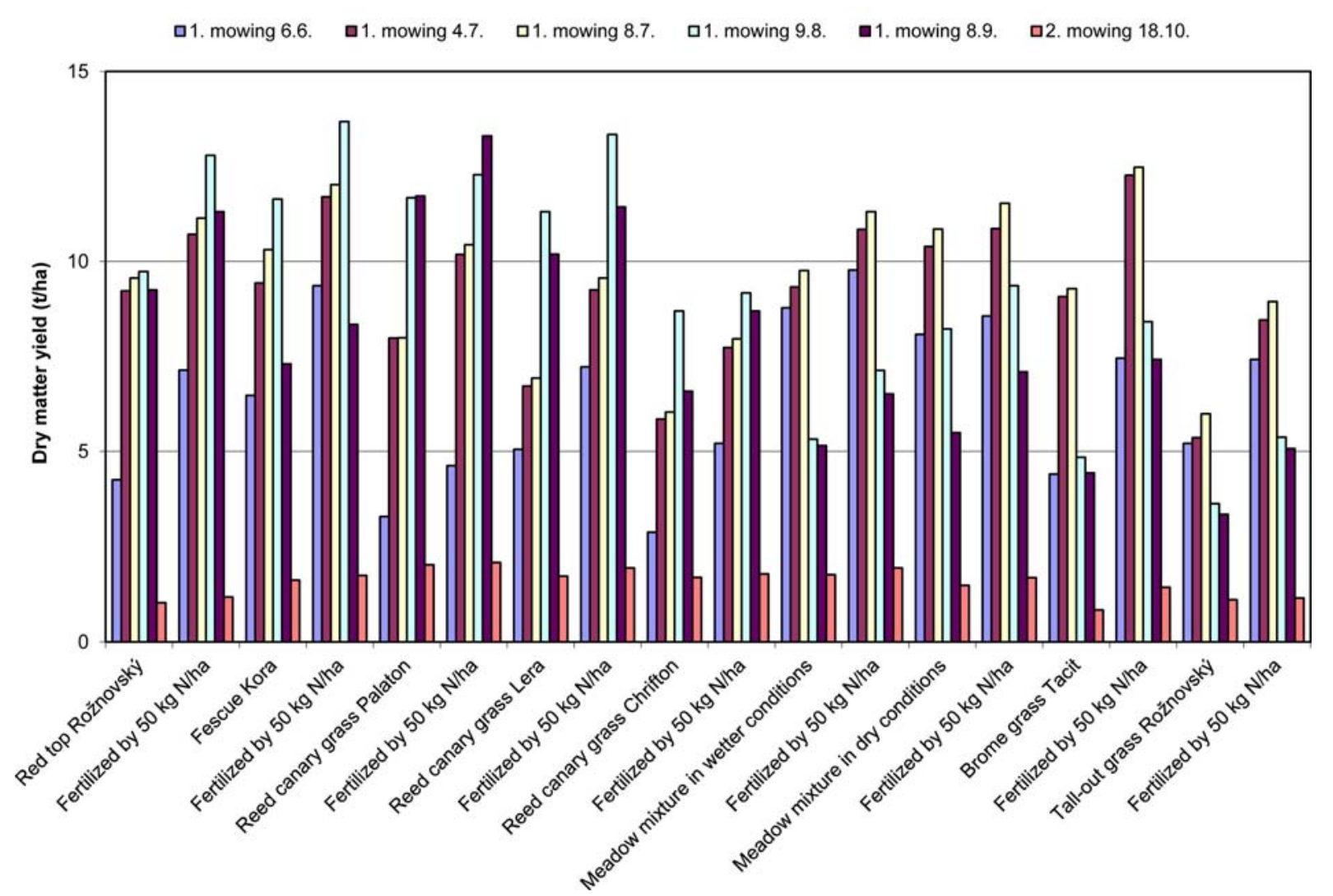

Figure 1: Produce of harvested grasses (D.M.) 


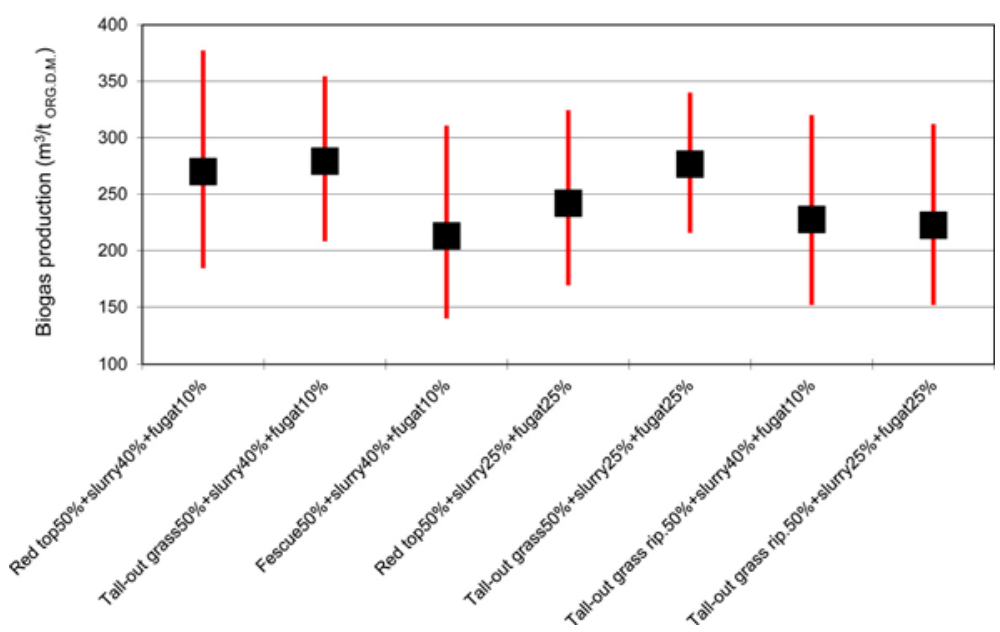

Figure 2: Biogas production for different blends

On September 8, the harvest of grasses and grassland mixtures for biomass production was performed. The dry matter content of the grasses and grassland mixtures ranged between $38.92 \%$ and $63.21 \%$. The highest dry matter content was found for bromegrass Tacit, $62.53 \%$ in the non-fertilized variant, and $63.21 \%$ in the fertilized variant. The highest yield of green material $(22.74 \mathrm{t} / \mathrm{ha})$ was for reed canary grass Palaton, in the fertilized variant. The highest yield of dry matter was also found for reed canary grass Palaton (13.30 t/ha), in the fertilized variant.

The second cut of the investigated grassland mixtures and grasses in the first year took place on October $18^{\text {th }}$. The second cut was harvested on the plots where the first cut had been made on June 6 . The dry matter content in the green material of the grassland mixtures and grass species ranged from $31.92 \%$ to $39.59 \%$. The results for the green material yield were from $2.56 \mathrm{t} /$ ha to $5.62 \mathrm{t} / \mathrm{ha}$. The investigated grassland mixtures and grasses showed a minimum difference in green material yield between the fertilized variant and the non-fertilized variant. After the first cut, no further fertilization was carried out. The highest yield of green material was for reed canary grass Lera, in the fertilized variant $(5.62 \mathrm{t} / \mathrm{ha})$. The highest yield of dry matter was found for reed canary grass Palaton, in the fertilized variant $(2.09 \mathrm{t} / \mathrm{ha})$. The dry matter yield ranged from $1.03 \mathrm{t} /$ ha to $2.09 \mathrm{t} / \mathrm{ha}$ in both the fertilized variant and the non-fertilized variant.

\subsection{Procedure for determining the biogas yield}

The biogas production, and its chemical composition, from each type of substrate was investigated. The two reactors enabled the fermentation blend compo- sition to be optimised, the course of the process to be better controlled, and the operational temperature effect to be monitored. For inoculating the process of methanogenesis, we used a blend of fermented fugat from the RAB Třeboñ biogas plant and fresh pig slurry, also from Třeboň. Identical conditions were set up for all the experiments. The fermenters operated at a temperature of $42^{\circ} \mathrm{C}$, i.e. within the thermophilic field. The dry matter weight percent of the initial blend of mixed substratum was between 4-8\%. The resulting biogas production (in litres) was always related to a mass of $1 \mathrm{~kg}$ of the sample organic dry matter.

\section{Conclusions}

The grassland mixtures and grass species that were included in the project revealed a different dry matter content in the green material, which increased mainly due to vegetation ageing and a later first harvest time. The highest dry matter content was found for plants harvested in September (for brome-grass in the fertilized variant, the dry matter content in the green material was $63.21 \%$ ). Particular grassland mixtures and grass species also react differently in terms of dry matter yield and optimum harvest time for biomass and its utilization for energy purposes during the harvest year. The aim is to achieve the greatest possible dry matter yield. The reduction in dry matter yield for grassland harvested later in the summer and in autumn in the first cut is due to leaf fall and plant lodging (e.g. grassland mixtures or Arrhenatherum elatius). On the basis of the preliminary results, it is recommended to harvest grassland mixture in wetter conditions and in dry conditions in June and July, with the possibility of using multicut. For these mixtures, in particular, the high yield potential of green material in an early cut can be utilized. 
Our preliminary measurements have shown the possibility of using a high proportion of agrostis gigantea in the batch. The biogas production from the mixture with agrostis gigantea is fully comparable with the biogas produced from slurry alone. Average yields of $265 \mathrm{~m}^{3} / \mathrm{t}_{\text {org.d.m. }}$ are normally achieved, and the maximum yield achieved was $378 \mathrm{~m}^{3} / \mathrm{t}_{\text {org.d.m. }}$. This yield was for Agrostis gigantea, one month before it reached technical ripeness. Very good results were also achieved for Arrhenatherum elatius, where the span between maximum and minimum production was smallest. Fescue seems to be a less suitable plant for biogas production. With the extended reaction time, there is stagnation in biogas generation and a drop in methane content after 33 days. All the tests proved the suitability of using young plants up to two months before they attain technical ripeness. When the harvest was made one month after ripeness, the results were significantly worse. Other trials focus on the effect of the grass species structure.

The combustion trials have proved that grass can be combusted in selected combustion systems and at the same time comply with the emission limits. It has also been proved that Agrostis gigantea and fescue are suitable fuels. For combustion purposes, it is suitable to do the harvesting as late as possible after the plant reaches technical ripeness [2].

The sieve mesh size for Agrostis gigantea crushing before pressing the briquettes did not influence the emissions. It only influenced the quality of the briquettes. Arrhenatherum elatius seems to be less suitable as a fuel.

In future work, other grasses, i.e. brome-grass and reed canary grass, will be tested in blends. There is also a legislative problem with grass combustion, since the boiler is allowed to incinerate only approved fuels. Until now, large boilers have been approved only for wood and straw combustion, and small boilers have been approved only for wood combustion.

\section{Acknowledgement}

The results presented are part of grant project No. QI101C246 "Use of the phytomass from permanent grassland and landscaping" supported by the National Agency for Agricultural Research of the Czech Republic (NAZV ČR).

\section{References}

[1] Andert, D., Gerndtová, I., Hanzlíková, I., Frydrych, J., Andertová, J: Wet grass utilization for energy. In Energetika a životní prostředí. Moderni energetické technologie a obnovitelné zdroje 2006, VŠB-TU Ostrava, Ostrava : VŠB-TU, 2006, s. 86-89. ISBN 80-248-1108-1.

[2] Andert, D., Sladký, V., Abrham, Z.: Energy utilization of solid biomass. Prague : VÚZT, 2006, č. 7, 59 s. ISBN 80-86884-19-8.

[3] Mužík, O., Abrham, Z.: Ekonomická a energetická efektivnost výroby biopaliv. [Economic and Energy Efficiency of Biofuel Production]. AgritechScience [online], Praha, [cit. 2011-12-27], 2011, roč. 5, č. 3, s. 1-4. ISSN 1802-8942.

[4] Hutla, P., Jevič, P.: Vlastnosti topných briket z kombinovaných rostlinných materiáli̊. [The Properties of Heating Briquettes from Combined Plant Materials] AgritechScience [online], Praha, [cit. 2011-12-27], 2011, roč. 5, č. 3, s. 1-5. ISSN 1802-8942. 